Article

\title{
Citizen Action as a Driving Force of Change. The Meninas of Canido, Art in the Street as an Urban Dynamizer
}

\author{
María José Piñeira Mantiñán * (1) Francisco R. Durán Villa and Ramón López Rodríguez \\ Department of Geography, University of Santiago de Compostela, 15782 Santiago de Compostela, Galicia, Spain; \\ francisco.duran@usc.es (F.R.D.V.); ramonlopez.rodriguez@usc.es (R.L.R.) \\ * Correspondence: mariajose.pineira@usc.es; Tel.: +34-88181100 (ext. 12626)
}

Received: 20 December 2019; Accepted: 15 January 2020; Published: 20 January 2020

check for updates

\begin{abstract}
The austerity policies imposed by the government in the wake of the 2007 crisis have deteriorated the welfare state and limited neighborhood recovery. Considering the inability and inefficiency on the part of administrations to carry out improvement actions in neighborhoods, it is the neighborhood action itself that has carried out a series of resilient social innovations to reverse the dynamics. In this article, we will analyze the Canido neighborhood in Ferrol, a city in north-western Spain. Canido is traditional neighborhood that was experiencing a high degree of physical and social deterioration, until a cultural initiative called "Meninas of Canido," promoted by one of its artist neighbors, recovered its identity and revitalized it from a physical, social, and economic point of view. Currently, the Meninas of Canido has become one of the most important urban art events in Spain and has receives international recognition. The aim of this article is to evaluate the impact that this action has had in the neighborhood. For this, we conducted a series of semi-structured interviews with the local administration, neighborhood association, the precursors of this idea, merchants, and some residents in general, in order to perceive the reception and evolution of this action.
\end{abstract}

Keywords: urban art; Neighborhood Regeneration; Social Empowerment; Right to the City; Ferrol (Spain)

\section{Introduction}

Over the last decade, citizen-administration relations in Spain have worsened. The austerity policies implemented in the wake of the 2007 financial crisis have resulted not only in political and institutional disaffection but also in a social and cultural crisis that has affected a high percentage of citizens. From the closing of companies and high unemployment rates (especially among young people) and eviction processes, the budget cutbacks (especially in personnel and basic services [1,2] and the privatization or externalization by subcontracting of some of them) have led to a notable worsening in citizens' living conditions [3-5]. The result has been an increase in the dynamics of social exclusion that have deteriorated the social cohesion of cities, leaving families and individuals in precarious conditions and in situations of vulnerability. According to the Eighth Report on Poverty in Spain [6], 8\% of the population suffer from cold at home (in 2009, it was 7.2\%), a quarter of those over 25 years old do not have their own income or earn less than 535 Euros a month, and $10 \%$ of workers continue to lose $25 \%$ of their income each year due to precarious job conditions. Additionally, regarding the housing problem and according to judiciary statistics, evictions continue, with a total of 368,591 recorded since 2013 , of which $58.9 \%$ were for non-payment of rent and $41.1 \%$ for non-payment of mortgages [7].

In this context, it is not surprising that more and more cities and neighborhoods are immersed in a deep and long-lasting decline [8-12]. They are vulnerable neighborhoods where degradation 
and neglect have been noted in the urban frame [13]. Numerous researchers have echoed the situation, analyzing the impact of the processes of negotiation of disposition [14], how austerity policies affect citizens' rights $[15,16]$, and how gentrification and tourism affect the aggravation of the population's vulnerability, limiting access to housing due to the increase in purchase and rental prices $[7,17,18]$. Likewise, the central government has tried to analyze the problem by creating a vulnerability observatory published by the Atlas of Urban Vulnerability and the Atlas of Vulnerable Neighborhoods. Thanks to them, an overview of the problem is available, but viable policies and initiatives that mitigate this vulnerability are still lacking.

Since 2011, civil society has organized itself in different movements, platforms, and associations to demand the stoppage of austerity policies and cuts and demand that access to basic social services be guaranteed. However, due the inability and inefficiency of administrations to carry out improvement actions, it is the neighborhood action itself that carries out a series of resilient social innovations to reverse neighborhood dynamics. To analyze them in this article we will focus on the Canido neighborhood in Ferrol, a city in the northwest of Spain. Canido is a traditional neighborhood affected by a high degree of physical and social deterioration, from which a cultural initiative has managed to reverse this deterioration, improving its physical aspect and energizing it from an economic, social, and cultural point of view. With its study, a double objective is pursued: first, to analyze to what extent the citizen movements of the neighborhood and their actions are the architects in the recovery of the neighborhoods and the reduction of their vulnerability, and also to study the degree of impact that these types of actions have in the neighborhood from a physical, economic, and social point of view and to what extent local administrations view them as a solution to the state of crisis in which they are still immersed.

To do this, we will first approach the urban policies that have been developed in Spain since the 1990s. We will check which urban sectors have been most interested in local administrations to make improvements and project an image of a concrete city. Later, we will study to what extent the social movements and their proposals for social innovation are helping to recover the quality of life in the neighborhoods. We will analyze some of them and consider if the administrations have supported them. Finally, we will analyze how the street art initiative Las Meninas de Canido has become the most attractive neighborhood in the city and has achieved international recognition.

\section{Objectives and Method}

To analyze the impact that the artistic experience of Las Meninas de Canido has had on the neighborhood, an eminently qualitative investigation that aims to accomplish the following objectives has been carried out:

- Analyze the extent to which cultural initiatives promoted by citizens are able to regenerate degraded spaces and increase the feeling of empowerment and identity of its inhabitants.

- Check to what extent these initiatives, which have arisen as popular resilience events, remain as such over the years, or if they have changed with respect to their beginnings.

- Know the perception that the inhabitants of the affected neighborhoods have towards such cultural initiatives and what their future prospects are.

To this end, an important review of the current literature on new models of urban governance, urban renewal and social innovation, social justice, neighborhood movements, and resilience and urban innovation initiatives (urban gardens, art in public space, etc.) was first carried out. The result was a theoretical approach to the issue.

Second, numerous websites and blogs have been consulted on Las Meninas de Canido, as well as the official websites of the municipality of Ferrol and neighborhood associations, to have some initial information on the projects that have been carried out in the neighborhood and thus be able to organize and design the questionnaire that laid the basis for the semi-structured interviews. 
The questions were organized into two large blocks (Table 1): one related to the Meninas event with questions that allowed the origin of the event to be known and to assess the degree of impact in the neighborhood, physically, socially, and economically; and another related to the neighborhood, to evaluate the sectors that were most degraded and see to what extent they were acting on them.

Table 1. Questions for interviews.

\begin{tabular}{cc}
\hline Las Meninas Block & Neighborhood Block \\
\hline $\begin{array}{c}\text { How did the idea come about? } \\
\text { Who participates? }\end{array}$ & $\begin{array}{c}\text { Has the identity of the neighborhood been reinforced } \\
\text { thanks to Las Meninas? }\end{array}$ \\
$\begin{array}{c}\text { In what areas are Las Meninas painted? How are the } \\
\text { areas to be painted organized (more degraded, } \\
\text { continuity with the previous ones)? }\end{array}$ & $\begin{array}{c}\text { Have Las Meninas been the true driving force of the } \\
\text { neighborhood? }\end{array}$ \\
$\begin{array}{c}\text { Is the popular character of the event maintained? } \\
\text { To what extent have the Meninas de Canido promoted } \\
\text { the city of Ferrol and the neighborhood of Canido? } \\
\text { To what extent does the city council participate } \\
\text { (financial contribution, services, etc.)? }\end{array}$ & $\begin{array}{c}\text { Have you favored the opening of new business? } \\
\text { To what extent have they influenced urban } \\
\text { regeneration processes? }\end{array}$ \\
$\begin{array}{c}\text { What will happen when there are no walls left } \\
\text { to paint? }\end{array}$ & $\begin{array}{c}\text { Can gentrification processes associated with the } \\
\text { rehabilitation and sale of homes be observed? } \\
\text { Have prices increased? }\end{array}$ \\
How many artists and works are there? & What new projects are there for the neighborhood?
\end{tabular}

The people/institutions interviewed were Eduardo Hermida, the person who, in an act of protest against the state of ruin and degradation in which the Canido neighborhood had become, went out and painted the first Menina, thus becoming the promoter of the cultural event of Las Meninas de Canido. Jorge Suárez Fernández, Mayor of the city from 2015-2019 and the person who assessed the degree of involvement that the city council had with the event; the association of Neighbors of Canido, the cultural association O Muiño, hoteliers, and merchants. All of them were allowed to give their opinion on the event of Las Meninas in order to evaluate to what extent the neighborhood has been transformed for them in recent years, to know what aspects they value as positive and negative, in relation to both the event itself, and the situation in which the neighborhood is, and to know its future expectations.

Likewise, the field work carried out in May 2019 in the Canido neighborhood allowed us to check the state of deterioration, the humanization actions carried out through European funds through urban projects and to map the location of the existing Meninas paintings in the neighborhood.

\section{The Paradigm Shift in Urban Policies}

In each city, there is a trajectory that indicates the balances between the role of public authorities, the business world, social fabric, or citizens in the processes that have combined urban transformation, the construction of a city model, and the dynamics of urban governance [19]. If we review the period from the mid-1980s to the present, we can see that the 2007 crisis was a turning point, both in relation to the desired city model, and therefore, of urban policies and outbreaks of interest to be addressed, including the agents involved and the expected results. For two decades, local administrations opted to create competitive cities within the global and modern market, in which urban megaprojects-often linked to international events-were the protagonists and placed the city on the map [20]. Examples include the Olympic city of Barcelona, the equipment and facilities built in Seville and Zaragoza with the universal exhibitions, the Guggenheim in Bilbao, the city of arts and sciences of Valencia, or the city of culture in Santiago de Compostela. With the exception of Bilbao, the viability of these projects has been questioned since their inception. However, they have always defended themselves from the political spheres under the pretext of the economic profitability that they would bring to the city and the improvement that they would provide at an urban level. From the administrations, a neoliberal growth model was chosen, in which the market and the real estate developers marked the growth of the city, and there was a liberalization of the land and a total deregulation of urban growth. 
The creation of new infrastructure was considered to improve the positioning of cities in the urban hierarchy, and investment in housing was understood as a safe and highly profitable asset. The city looked like a business, and therefore, getting the maximum benefit was the key objective. Throughout this process, financial institutions played a key role, offering loans with generous conditions, both for real estate developers and for citizens, who were encouraged to apply for a mortgage to purchase their homes [21-23]. The result was unprecedented urban growth, in which the traditional city lost its meaning in the face of urban sprawl processes and in which the city was considered a consumer product, where all aspects that had to do with the social welfare and quality of life of citizens were relegated to the background. In this regard, it should be noted that while comprehensive development strategies have been implemented in Spanish cities since 1994, through initiatives funded with European funds. These include URBAN and URBAN II initiatives, Urban Innovative Actions (URBACT), and Integrated and Sustainable Urban Development Strategy (ISUDS). In relation to the former, its objective was to combat urban degradation and promote the regeneration of degraded neighborhoods. With them, it was possible to introduce in Spain a series of concepts that were not yet discussed. These include the concept of an integrated approach, the need to address the problems of cities based on collaboration between institutions, the need to involve the population and local actors through participatory processes and the introduction of a vision of urban regeneration based on the concept of sustainable urban development. In the period 1990-1994, there were 29 URBAN projects that involved an investment of $€ 16,748,739$; while with Urban II (2000-2007), only 10 were counted [24]. On the other hand, the URBACT initiatives (2014-2020) were aimed at promoting sustainable development in 28 Spanish cities, with an investment of $€ 351,820$ [25]; at the same time that for the Integrated and Sustainable Urban Development Strategy (ISUDS), more than one billion euros were allocated to improve the environment, promote social inclusion and the fight against poverty, improve access to ICTs and improve environmental quality [26]. Nevertheless, there are few studies on the impact that these have had when solving specific problems of a social, environmental, and economic nature in the sectors involved. In some cases, these funds were used to improve some sectors of downtown areas of cities, historic centers, or neighborhoods with degraded buildings, but they continued to be small urban acupuncture interventions [27]. The problem was that most of the municipal investments made were destined for actions that could attract a greater number of visitors or tourists; leaving the neighborhoods in practically the same state of degradation and vulnerability in which they started. In 2007, the urban development model changed completely, because:

- With the crises, the weaknesses of the neo-liberal growth model came to light, uncovering some cases of corruption linked to it [28], becoming, in 2015, the second problem that most worried Spanish citizens after unemployment, according to data from the Center for Sociological Research [29].

- Local administrations were aware of their degree of indebtedness derived from the construction of megaprojects and saw their budgets cut because debt forgiveness was a priority for the central government.

- Citizens demanded a new way of creating a city and recovering the right to the city and real democracy. According to Harvey [30], in Spain, the clamor for the right to the city meant insisting on the right to change and reinvent the city based on the wishes of the people who inhabit it. In this context, civil society took to the streets, following demonstrations and the emergence of citizen platforms from which the new leftist parties emerged that would arrive in the 2015 elections to the municipal governments of cities such as Madrid, Barcelona, Cádiz, A Coruña, Santiago de Compostela, and Ferrol. Some parties promised their citizens the defense of democratic rights, an end to corruption, a restoration of the well-being of citizens, a guarantee true democracy, and service to the vulnerable population [31-34].

From then on, talk about local government gave way to talk about urban governance, in which both the policies and the actors involved in them mattered. Among them were the citizens, who had 
become increasingly empowered. The interest of these policies focused on neighborhoods, especially those that were the most vulnerable and where there was greater unemployment and more evictions. It was based on the premise that the city should be a space to live and a place for citizens and that the administration had to be the one to guide the strategies that needed to be developed, with the help of citizens through real participation, in a way that decisions were not imposed but worked from the bottom up; transparency departments were created, and municipal budgets were redistributed by increasing the budget of the most disadvantaged neighborhoods to promote social rental housing, promote educational and cultural activities, and serve the most disadvantaged groups (youth, long-term unemployed, women, single parents) to improve their quality of life (Table 2).

Table 2. Keys of urban policies changes during the post-crisis period.

\begin{tabular}{|c|c|c|}
\hline Key Elements & 1990-2007 & 2008-2019 \\
\hline Model of urban governance & $\begin{array}{l}\text { Creating a modern and competitive city } \\
\text { image } \\
\text { Efficiency was established by private } \\
\text { sector measures } \\
\text { Contingent on the market }[22,23] \\
\text { Top-down control of power and } \\
\text { decision-making [19] }\end{array}$ & $\begin{array}{l}\text { City: a space to live and a place for } \\
\text { citizens [35] } \\
\text { Restoring the role of the state [27] } \\
\text { Multilevel governance that } \\
\text { incorporates social action [36] } \\
\text { Restoring democratic values } \\
\text { [37-39] } \\
\text { Need for a new economic order } \\
\text { Bottom-up decision-making and a } \\
\text { new institutional structure [40] }\end{array}$ \\
\hline Urban planning & $\begin{array}{l}\text { Subjecting planning to market interests } \\
\text { [41,42] } \\
\text { Builders define urban development [43] } \\
\text { Administration has a secondary role } \\
\text { Land liberalization and building at all } \\
\text { costs [23] } \\
\text { Deregulation of urban and spatial } \\
\text { planning [23] } \\
\text { Lack of coordination between urban } \\
\text { policies [19] }\end{array}$ & $\begin{array}{l}\text { Establishment of urban planning } \\
\text { criteria to halt deregulation [44] } \\
\text { Administration plays a leading } \\
\text { role in planning [23] } \\
\text { Encouraging participation in } \\
\text { neighborhoods Interaction in } \\
\text { actors' network [45] } \\
\text { Realistic budgets that conform to } \\
\text { actual needs } \\
\text { Focusing investments on } \\
\text { vulnerable neighborhoods }\end{array}$ \\
\hline Focus of interest & $\begin{array}{l}\text { Entrepreneurial city [46] } \\
\text { Construction of housing, installation } \\
\text { and infrastructure megaprojects [47] } \\
\text { Urban sprawl and metropolitan spaces }\end{array}$ & $\begin{array}{c}\text { Promotion of social and economic } \\
\text { innovations } \\
\text { Development of dynamic projects } \\
\text { Overcoming social, economic and } \\
\text { housing insecurity } \\
\text { Citizen mobility [48] } \\
\text { Cities being resilient and } \\
\text { alternative (ways of being resilient, } \\
\text { having alternative economies) } \\
\text { spaces [8] } \\
\text { Right to the city } \\
\text { Right to housing }\end{array}$ \\
\hline Key players & $\begin{array}{l}\text { Banks, financial institution and the } \\
\text { administration [23] }\end{array}$ & $\begin{array}{c}\text { The administration } \\
\text { Empowered citizens }[49,50]\end{array}$ \\
\hline Results & $\begin{array}{c}\text { Overextended growth of cities and } \\
\text { metropolitan areas } \\
\text { Loss of value in cities } \\
\text { City becoming a product } \\
\text { Dismantling of the welfare state } \\
{[9,51,52]}\end{array}$ & $\begin{array}{c}\text { Planning of model cities } \\
\text { Understanding the city as a whole } \\
\text { Value of neighborhoods } \\
\text { Priority for the well-being of } \\
\text { citizens } \\
\text { Greater quality of life }\end{array}$ \\
\hline
\end{tabular}

However, after four years since the arrival of these political parties, the interviews with policy makers in cities such as Madrid, Cádiz, Valencia, A Coruña, and Ferrol have revealed that the expected 
results have not been obtained. Among the causes is the budget deficit, the difficulty of changing work synergies established for decades in local administrations, excessive bureaucratization, and even reluctance on the part of the opposition parties when implementing some initiatives, such as those that favor the creation of public housing for social rent. Consequently, citizens continue to be the protagonist when it comes to implementing social innovation actions that mitigate the situation of degradation and vulnerability that still exists in neighborhoods.

\section{Citizen Movements and Social Innovation: Two Key Factors for the Recovery of Neighborhoods}

In Spain, neighborhood communities have become the mechanism to combat vulnerability and the lack of social cohesion. They are the nexus between the search for a democratic state guaranteeing basic rights on the one hand and the continuous reinvention of social life on the other [53]. They are the loci and drivers of social innovation aimed at improving the neighborhood environment and recovering the sense of a lost neighborhood, turning public spaces and abandoned buildings into self-managed meeting places. Consequently, a multiplicity of structures to govern/manage neighborhoods has emerged, in collaboration with the local administration, which has increasingly given greater importance to initiatives that encourage the revitalization of the urban environment arising from civil society $[40,53]$. Its success has been conditioned by the level of citizen mobilization, the degree of awareness and empowerment of neighbors, as well as their ability to learn. The result is that neighborhoods have become laboratories in which to test all kinds of innovative actions that result in dynamics of urban and social improvement.

But what does social innovation consist of? Depending on the discipline from which their interpretations are approached, they range from management, where social innovation is understood more as a product than a process [54] to which they have a more systematic approach, contemplating aspects such as the network of actors, the type of relationship and interdependence with public administrations, the overlapping of the territory and other contextual factors (social, cultural, political) as well as the objectives, the type of process and its social effects [55]. Another point of view is that which links social innovation to creative citizen practices that are carried out in neighborhoods and cities, conceived from social movements (community or civil platforms), considering that the welfare state has deteriorated and therefore there is an insufficient response capacity to meet the collective and individual needs of the community. Among them, we can highlight the following points:

- Innovative actions related to the different phases of the economic cycle (production, distribution, financing, or consumption). Among them, we can differentiate those of a formal and informal nature, from cooperatives and associations to organic produce consumer groups, where intermediaries are eliminated, or to projects such as social currency or barter markets. In this field, the population has mobilized looking for an alternative economy from which ethical banking or crowd funding are born. Financial alternatives to the existing ones, where the maximum benefit is not sought, are able to carry out projects thanks to the collaboration and cooperation of different agents. This group also includes actions such as time banks, in which participants exchange their skills for time instead of money, where hours are added when a service is provided to another participant and subtracted when you are the beneficiary of the service.

- Social innovation actions linked to participatory processes from which ideas are collected to carry out some urban interventions in the neighborhood. In this case, we want to highlight the Los Madriles project (Figure 1), started in 2015, which consists of an atlas of collectively generated neighborhood initiatives. Its objective is to generate a network between the different projects that are underway in Madrid and that share a social vision and community intervention. This initiative stands out for the diversity of promoters who managed to put the website into operation: the Federation of Neighborhood Associations of Madrid (FRAVM), Zuloark, the citizen initiatives incubator, all for praxis and Transversal Landscape collectives, social and neighborhood groups, 
and Intermediae, an experimental space devoted to socially engaged artistic practices approached from the angle of research and cultural innovation.

- Social innovation actions linked to the urban environment of the neighborhood, carrying out projects in the public space. In some cases, they are projects related to the environment-promoting more sustainable forms of access and use of resources - and the revitalization or recovery of the physical space, which will subsequently have a social impact. Self-management spaces that are developed in the public space and real estate. This group highlights the initiatives of urban gardens (Figure 2), small plots in which agricultural tasks are carried out with ecological farming methods, where the productive functions associated with family consumption are combined with social and environmental and which house a potential to develop activities of citizen participation. Its success has been so great that the number of urban gardens exceeds 15,000, in more than 300 municipalities. Among the initiatives aimed at recovering empty and degraded urban spaces, we can mention This is not a site in Zaragoza (Figure 2). It consists of the recovery of abandoned plots within the city, where a process of cleaning, rehabilitation, and maintenance makes them open spaces for neighbors. This results in the removal of abandoned spaces in urban and unused areas where rubbish usually accumulates. Empty plots are converted into public spaces, creating gardens, parks, or urban vegetable gardens among others.

- Social innovation action is linked to arts and creativity because culture can be the growth factor at the source of economic competitiveness and can also contribute to the social development and environmental sustainability of neighborhoods [56]. In this group, urban murals and paintings stand out. Artistic expressions are made in public space-buildings, facades, streets, and squares-with the aim of improving their image and recovering them not only from a physical point of view but also a social and economic one. In this sense, we must consider that some street art initiatives have resulted in urban regeneration, gentrification and tourism processes. However, while at first they can be valued positively since they revitalize the neighborhood, in the medium term, they can result in expulsion processes of the population due to the rise in housing and commercial real estate prices and the negative effects of mass tourism in specific urban sectors.

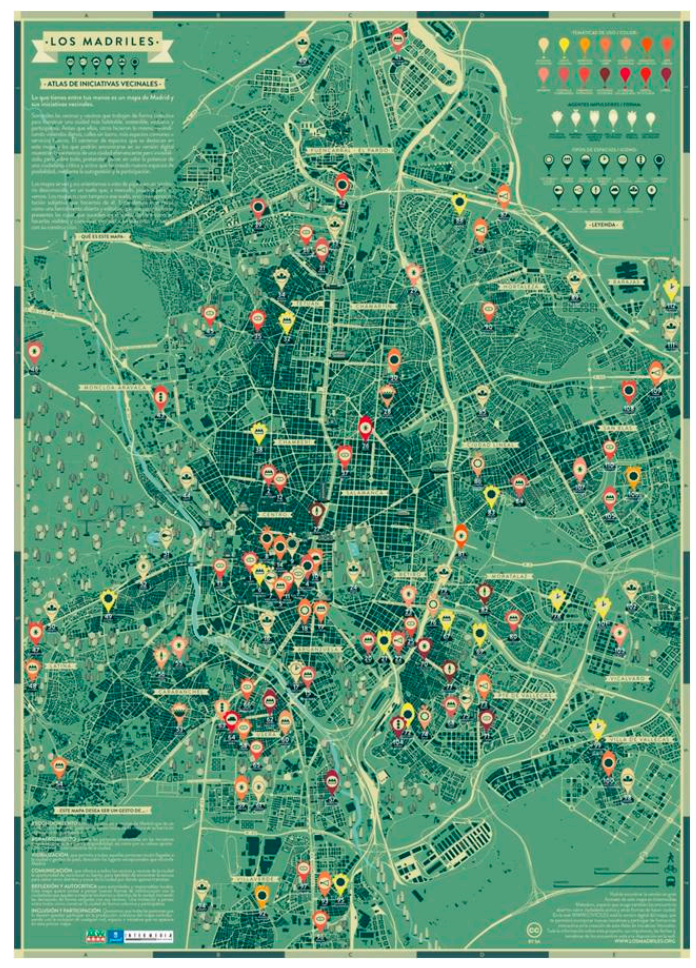

Figure 1. Los Madriles Map. 


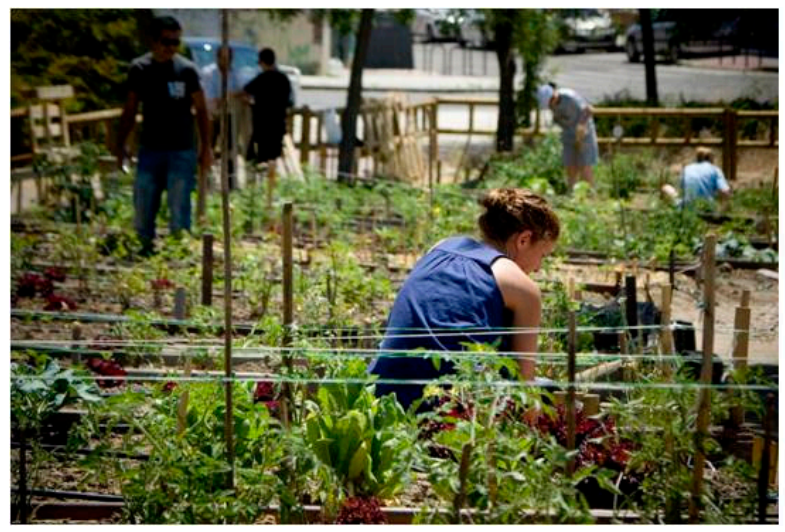

(a)

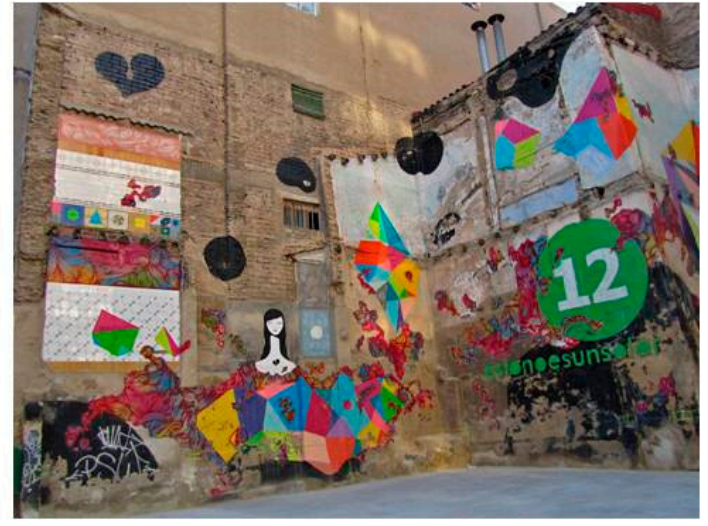

(b)

Figure 2. (a) Urban garden; (b) initiative in public space with the project This is not a site.

In the following sections, we will approach the regenerative effect that street art has had on urban spaces and later focus on the study of Las Meninas de Canido initiative and the impact it has had on the degraded Canido neighborhood.

\section{The Urban Recovery of Degraded Neighborhoods: The Effect of Street Art}

When talking about the impact of artistic performances in urban spaces, we must consider two key concepts: public art and urban art (also known as street art). Although both are developed in a common space, they differ in that public art is considered a legal artistic manifestation, insofar as it is part of the urbanization plans of the local administration and has a heritage character and is cared for; While urban art is performed by artists anonymously, it is considered illegal and has an ephemeral character [57]. Despite this, it is considered free and open access art [58].

However, some authors consider certain nuances between the concept of urban art and street art. They consider that the first is linked to the art of graffiti, as an artistic expression that generally contains a political or social criticism charge in its origins and associated with the imagery of vandalism, illegality, and protest, while street art, known as Postgrafiti, has a more artistic load, and its technique is more respectful than graffiti when choosing materials and support. Among its most used techniques are murals, stencils, stickers, and posters, some of which are commissioned $[59,60]$.

In any case, in this article, we do not intend to respond to the difference between these expressions or to debate whether graffiti is an artistic movement or not. What is intended is to highlight how an artistic activity such as murals or graffiti has become fashionable in recent years and is a common practice in those parts of the city most physically degraded. Thus, culture becomes a catalyst that triggers the reuse of abandoned spaces and the creation of new urban scenes; it can be a source of urban revitalization and social inclusion. Like a human body patterned with tattoos [61], degraded sectors are commonly covered with inscriptions that are already part of the urban imaginary [62]. Then, an aestheticization of everyday life is produced [63], in which images acquire a new and central role in the society of consumption. However, there is a debate about the contributions of the culture and public art industry for urban restructuring and regeneration [64]. There is a paradox that, on the one hand, urban art is considered a measure that contributes to the improvement of public space and, consequently, the quality of life of residents. In addition, it favors citizen empowerment, the strengthening of the neighboring identity - as it tries to adapt to the social and historical context of the neighborhood-and social commitment by questioning, discussing, or giving effective aesthetic responses to the needs of citizens [65]. Nevertheless, the fact that urban art moves between the allowed, the regulated, and the illegal cannot be ignored. Sometimes, it is accepted, even being conserved and promoted; in others, however, it is criminalized and prohibited. 
However, there is no doubt about the number of festivals, publications, and urban art galleries that have arisen in different cities, in which the participation of local administrations is increasing, reaching directly to encourage the realization of these practices in concrete spaces in the city, with a clear objective: to commercialize art as an advertisement for tourism. However, there are some practices in which these cultural productions revert to the benefit of the community, the neighborhood, or the city.

Cases like The Bushwick Collective in New York (Figure 3) are true outdoor art galleries, which have transformed a shady industrial neighborhood into a vibrant tourist destination. It has attracted numerous street, local, national, and international artists and thousands of street art fans since its first mural in 2011 [66].
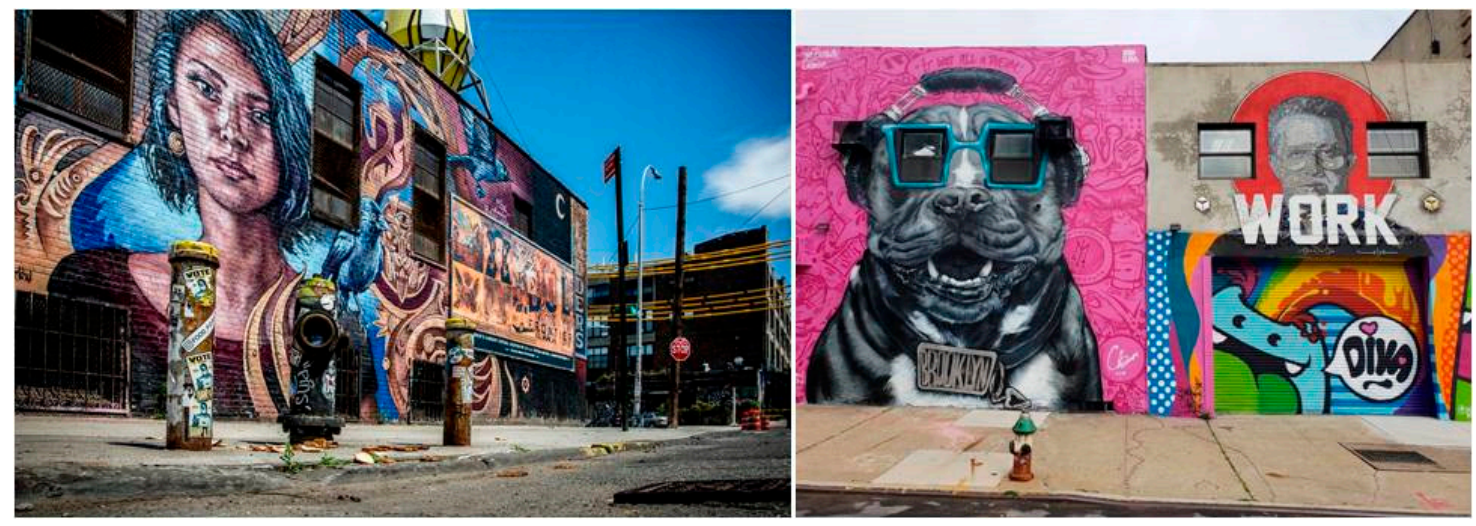

Figure 3. Murals of Bushwick Collective in New York.

Another similar initiative is Wynwood Walls, conceived in 2009 in Miami. The aim of the artist who had the idea was to look for something big to transform the Wynwood district, an area full of windowless warehouses, whose facades would soon become giant canvases in which to show the best street art. Since its inception, the Wynwood Walls program has had more than 50 artists representing 16 countries and has covered more than 80,000 square feet of walls. The New York Times, BBC News, Vanity Fair, and Forbes have included Wynwood in their list of the most modern neighborhoods in the United States [67].

\section{Street Art in the Canido Neighborhood: The Recovery of a Historically Stigmatized Neighborhood in the City of Ferrol}

The neighborhood of Canido, together with those of Ferrol Vello, La Magdalena, and the now-disappeared Esteiro, form the origins of an enlightened 18th century city, which emerged after the new naval policy of Felipe V came into force in 1726 in Spain (Figure 4). Its choice as the capital of one of the three maritime areas of Spain, the north, marked the beginning of the construction of an arsenal and shipyards, the orthogonal neighborhoods of Esteiro (known as the "frame " by its perimeter), the New Community of the Magdalena, and a whole series of defensive infrastructures materialized in the bastioned wall of the city and in the castles and batteries built on the margins of a natural port-the Ferrol estuary - an area of high geostrategic value until the first third of the 20th century [68].

The neighborhood is located on the top of a mountain to the north of the city with which it shares its name, between the cove of the Malata and the Magdalena neighborhood to the south, while in the west, it joins the early naval center of the old quarter. After successive proposals for fortification of the square, the one presented by the military engineer Pedro Torbé in 1768 definitively integrated this poorly populated rural space within the boundaries of the departmental city, being protected by one of the 12 bastions, known as Canido or Santiago. As well as its strategic nature, due to its altitude and exposure to the estuary, the peripheral and limit value in the administrative level can be added, 
a value that would play an important role in the process of expansion of the city from 1939 at the end of the civil war.

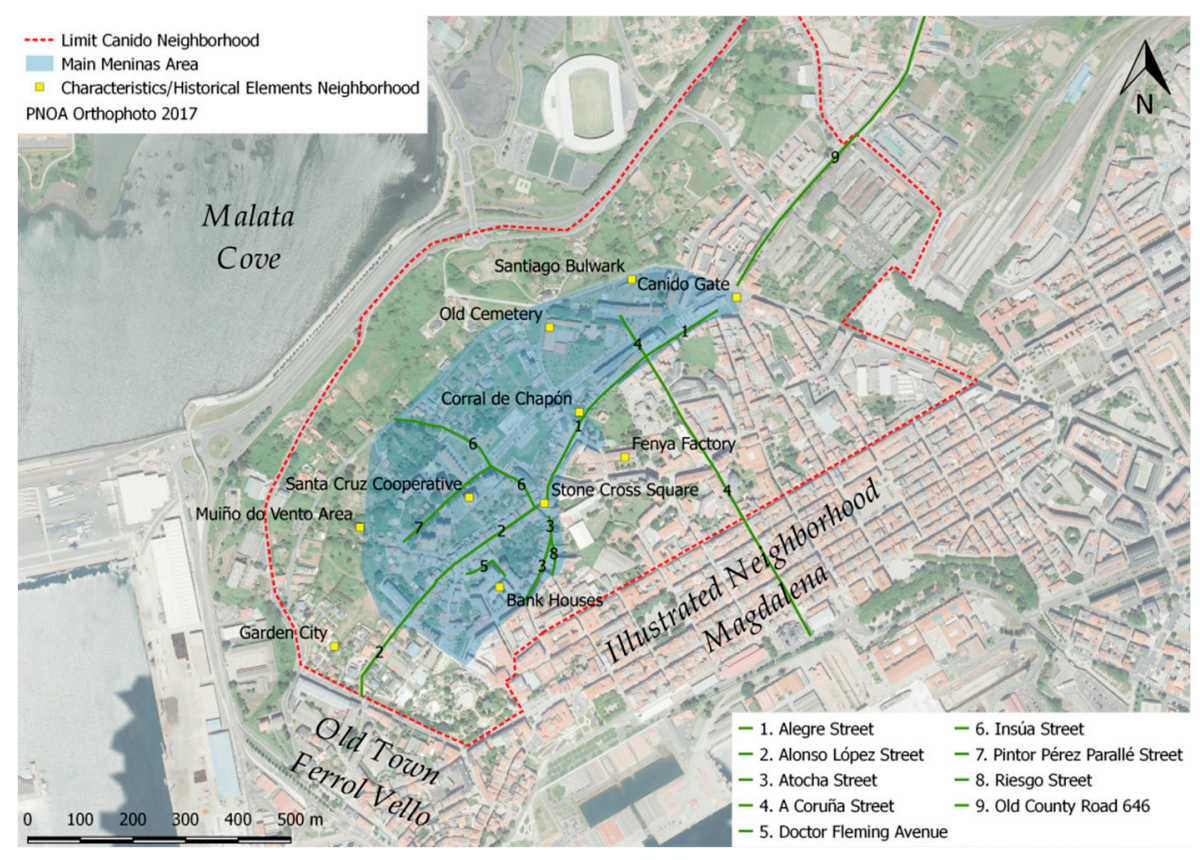

Figure 4. Canido neighborhood in the city of Ferrol.

Early reports refer to the place or village of Canido, which presupposes its earlier agricultural beginning, whose imprint is still noticeable in the traditional housing of the neighborhood. The rural exodus, attracted by the naval activity, would gradually turn this space into an alluvial neighborhood, capable of maintaining a part-time agricultural activity-unlike the one in Esteiro, erected from a new plant to house the shipyard workers and their families-supported mainly by women, who would have the opportunity to enter the labor market in one of the industrial initiatives (food, pencils, and textiles) from the 1940s. The male workforce was mainly concentrated in the shipyards of Bazán and Astano and participated in an increasingly diversified industrial sector, which was almost always related to the sea. Among others, the net factory (DEFER), PYSBE (Fisheries and Dryers of Cod of Spain), the Peninsular timber factory, the Hispania pencils factory, Soaps Pucho and properly in Canido the Fenya (Naval and Artillery Electrical Fabrications), the Piñon manufacturing company, and Industrial Pencils (ILASA). The settlement of workers in the neighborhood contributed to changing its physiognomy, causing profound internal social changes that were supported by the development of a militant commitment and solidarity strategies, which strengthened the affective and identity ties and generated a strong sense of belonging. While the bonding sentiment developed, initiatives at a parish level emerged to combat a daily life marked by the struggle against the difficulties of wages, hunger, poverty, inhuman housing, both parents working, and children in the street [69].

Its peripheral physical and structural origin, the peculiarities of its growth and development, as well as the recurring crises that plagued the city and its region were also accompanied by processes of social exclusion and segregation, materialized in perceptible forms of urban fragmentation and marginality, sometimes loaded with negative connotations and stereotypes, which were, without a doubt, defense strategies of the most favored groups to justify the existing social inequalities within the framework of the prevailing developmentalism. Stereotypes that can still be seen in the sociocultural imaginary and that condition the perception that some inhabitants of the city of Ferrol have of the neighborhood in general and in particular of its limits with the Magdalena neighborhood. The conformation as a structural periphery is related to the process of devaluation of the area that led to the opening of the municipal cemetery - the Canido cemetery-in 1804 after more than 25 years of heated controversies between the local authority and the neighborhood. On the other hand, 
the periphery, understood as a remote and disconnected space from the illustrated city, was favored with the opening of the street of San Eugenio in a north-south direction, which was immediately converted by citizens into the street of the dead and corresponds to the current street of La Coruña.

This fact, which responds to the implementation of sanitation budgets, was not isolated, as evidenced by the transfer or erection of new charitable welfare infrastructures in the open crossroads on the hillside, initiated with the opening of the new building of the charity hospital in March 1786, whose lands were acquired almost at the same time as those of the cemetery. Subsequently, this culminated with the nursery, the school for poor girls, the nursing home, and centers for social care and the company stores in the Dictatorship (1939-1975).

The presence of these institutions, together with the industrial enclaves, contained the prices of the abundant land and favored initiatives of private housing cooperatives-for example, the houses of the housing cooperative of Santa Cruz and, on a smaller scale, those of naval government officials, which were accompanied by the construction of the noncommissioned dwellings of the army at the door of Canido (currently Plaza de Canido, a newly created node) and by those built on the initiative of the Board of Trustees of Houses of the Navy for noncommissioned officers outside the entrance to Canido, extending the neighborhood to the east following the axis drawn by the old county road 646 and the newly built council housing. The emergence of these new promoters resulted in the emergence of new social upheavals and interior peripheries, degraded spaces located in the inner city, which in the past formed a periphery that was frozen in time [70] that materialized in an significant trade union and protest activity within the framework of specialized Catholic Action movements in the absence of democracy.

This construction fever began in the 1950s after the closure of the cemetery and fundamentally materialized in the decades of the 1960s and 1970s. This resulted in the expansion of the neighborhood to the east, and also to the west, coming into contact with the old quarter, where a small, upper class garden city arose, which was interwoven with the buildings that rise up the hillside as the northern extension of the Magdalena neighborhood, especially after the transfer from the hospital to the new dormitory suburb of Caranza and the opening of sections of the diagonal project dedicated to Doctor Fleming.

The increase in housing stock was accompanied by the improvement and opening of new urban roads and resulted in a significant increase in the population, whose immediate consequences were manifested in the erection of the new parish of the Holy Cross, which closed on 13 October 2019 after 55 years of operation, and the creation of public educational institutions for children and the current primary school—the Canido Infant and Primary Education Center (the former Reyes Catolicos school) - and the subsidiary of the women's institute on the grounds of the former graveyard, along with other private initiatives, all of which was accompanied by the proliferation of small commercial and artisanal activities to meet the demand of new residents.

To delimit the neighborhood is difficult. The Madoz dictionary [71] and the History of Ferrol de Montero Aróstegui [72] both break the space up as part of the Magdalena neighborhood or the historic center. At this time, the limits proposed by the city council coincided in the southern part with the layout of the grid of the enlightenment.

In line with its expansion process and its socio-economic peculiarities, urban deterioration processes do not affect all internal sectors equally. They are located mostly in the areas adjacent to the early roads that converge in the Stone cross square, the main node of the old enclave (Atocha-Riego, Alegre, Insúa, Alonso López), a crossing that has become an iconiclandmark of the neighborhoo, in the surroundings of the Plaza de la Tahona, Muiño do Vento, and in the corral of Chapón, which contrast more, if possible, with the recent estate built on the site of the old Fenya or on the new avenue of the painter Pérez Parrallé. It is worth noting that we are currently helping with the launch of major, new housing developments in the neighborhood [73], which support the recent prominence of this space in the framework of a city in perpetual crisis, due to both the decrease in the number of people living there and an aging population. It has been listed as the oldest city in Spain according to 2018 data from 
the Galician Institute of Statistics [74], since those over 64 represent $27.4 \%$ of the urban population, two points above the average of the region of Galicia (24.9\%).

This is also felt when you see that Canido currently has the lowest average age of the old walled enclosure-45.4 years, only surpassed by two small districts located in the greater area outside the gates that develops on the axis traced along the road of Castile, the main (and until 1968 the only) communication route that links it to the state road network. The best neighborhood in Galicia [75], as was recently awarded by Galician Television, is the result and recognition of an important neighborhood action that has managed to combine the historical legacy, secular traditions such as the exaltation of nature in May - Los Maios -, the recovery of old icons that give it its own personality, such as the Chapon yard, the bulwark, or the public laundry, with the strength of identity and belonging ties, the result of a hard shared experience, to undertake a whole series of strategies that allowed the deterioration and abandonment initiated with the naval crisis of the late 1970s to be left behind. From an identity of resistance [76], collectively and jointly built during the dictatorship, the residents of Canido have managed to rebuild it through a project based on elements of their collective culture. Its objective is to implement a neighborhood project through different initiatives that combine the complaint and visibility of problems with actions aimed at the sustainable improvement of the living conditions of the inhabitants, the recovery of heritage and public spaces both from the environmental point of view and also for living side by side, and encouraging new buildings that attract and settle new residents who collaborate on the path of demographic recovery and in the process of economic revitalization.

There are many initiatives that have been carried out, among which we can highlight the second-hand market [77]; the flowery orchards of Canido [78] (in which the environmental component is combined with the principles of land Art, the Mercalegre art market [79]); and fundamentally the street art festival, Meninas de Canido, in which cultural activity has become an important local development strategy. With this, the neighborhood has been reborn as a neighborhood that tourists visit again and, above all, that neighbors can enjoy again; a neighborhood in which new small businesses are emerging, in which children go out to play in the street and in which adults meet again in the bars of the stone cross square to have a drink; and a neighborhood in which the neighbors no longer leave, but new ones arrive [80]. The increase of the neighborhood in a city that loses an average of 800 inhabitants in the last year (770 in 2018) supports this collective project, which we will analyze in depth in the following sections.

\subsection{Las Meninas de Canido: the Art of the Museum on the Street}

Las Meninas de Canido is an artistic and cultural festival where image and sound take to the streets as a vindication of a living neighborhood in permanent transformation. Its origin dates back to 2008, when it arose as a complaint mechanism to the situation of deterioration in the Canido neighborhood in Ferrol, a neighborhood in which the population did not want to reside and where there was no business or investment.

The artist Eduardo Hermida was its promoter. According to Hermida, it hurt to see how the neighborhood he had grown up in was degrading. That is why, remembering his childhood when he painted the wall of one of the houses in his neighborhood with chalk, he decided to begin to capture art in its streets. For this, he chose one of his favorite painters, Velázquez, and among his works, he chose Las Meninas, because it is perhaps his most recognizable work.

His goal was twofold: on the one hand, with the color of the works, he wanted to give light to the facades-victims of abandonment, deterioration, or vandalism; and on the other, he sought to take art from museums to the street in order to offer free culture to people who had no means to visit a museum or go to a concert. This is how, in 2008, the colorful performance of the Meninas de Canido began. In that year, Eduardo Hermida invited a group of artists from diverse, new, and renowned trajectories to participate in a pictorial marathon that would last 12 hours. The idea was to represent the Meninas painting on the walls of degraded homes, as if they were a canvas. It was an activity 
buoyed by music and one in which the local residents played an active role by offering supplies to the participants. The municipality collaborated by donating the material for the realization of the paintings, and thanks to the successful day, the initiative was repeated in later years.

Over the years, the Meninas de Canido has become more popular both nationally and internationally, and its organizational model has changed.

- The city council wanted to show its support for the initiative by providing funds for the purchase of material, although its contribution is not enough.

- The number of participants increased. While Eduardo Hermida initially called well-known artists to join him, there are currently many artists requesting to participate in the event.

- Artistic techniques and activities (short films, poetry, dance, games for children, etc.) have been expanded.

- The modality of large murals has been introduced to hide the ugliness of the large medians in the urban landscape of the neighborhood. Among the stand-out murals are the contemporary interpretations of Las Meninas by artist Shfir, with the unmasked Menina (Figure 5), or the work of Lily Brik with a Menina tribute to the Infanta Margarita (Figure 5).

- If at the beginning they were only painted on the walls of abandoned homes, now it is the owners of the houses and the catering businesses that request that the Meninas be painted on their walls or streets. Likewise, homeowners who have been affected by rehabilitation processes that have occasionally deteriorated or destroyed the paintings on them, are requesting that their Meninas be restored.

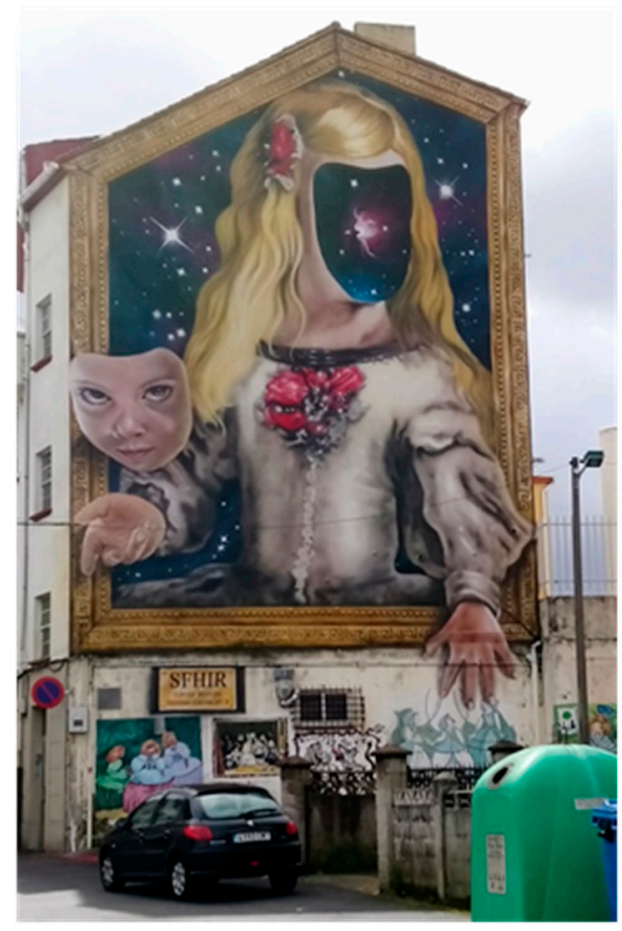

(a)

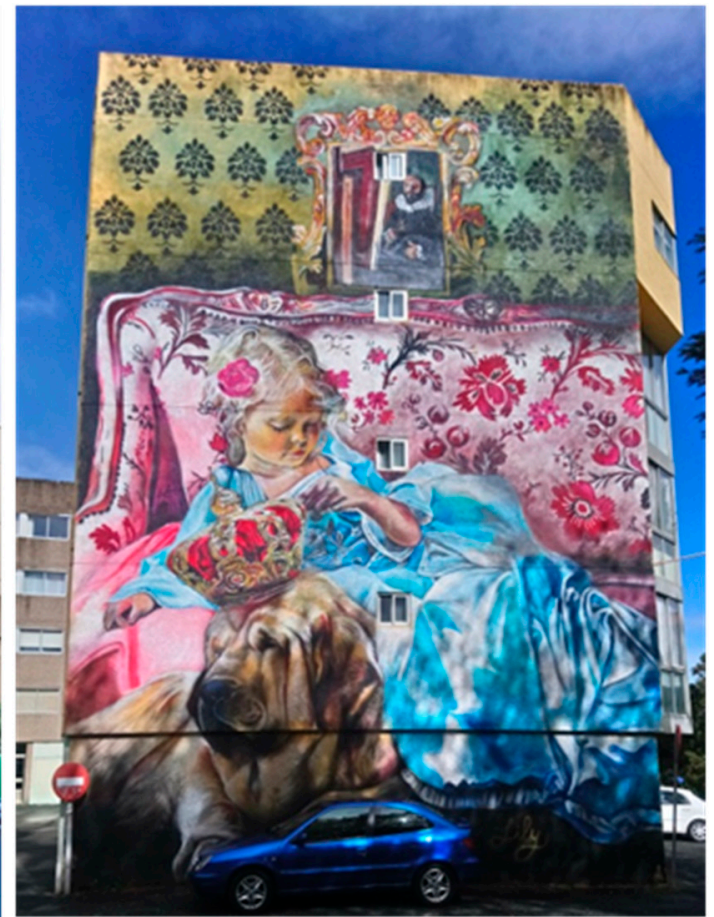

(b)

Figure 5. (a) Unmasked Menina Shfir; (b) Menina of Infanta Margarita Lily Brik.

The festival takes place in early September, and the 2018 edition welcomed more than 100,000 visitors. Since its inception, more than 1200 artists have participated in it, some from Syria, Slovenia, Poland, Brazil, or Taiwan, which gives the neighborhood a universality. Along its streets, there are more than 300 pictorial works that can be enjoyed (Figure 6). 

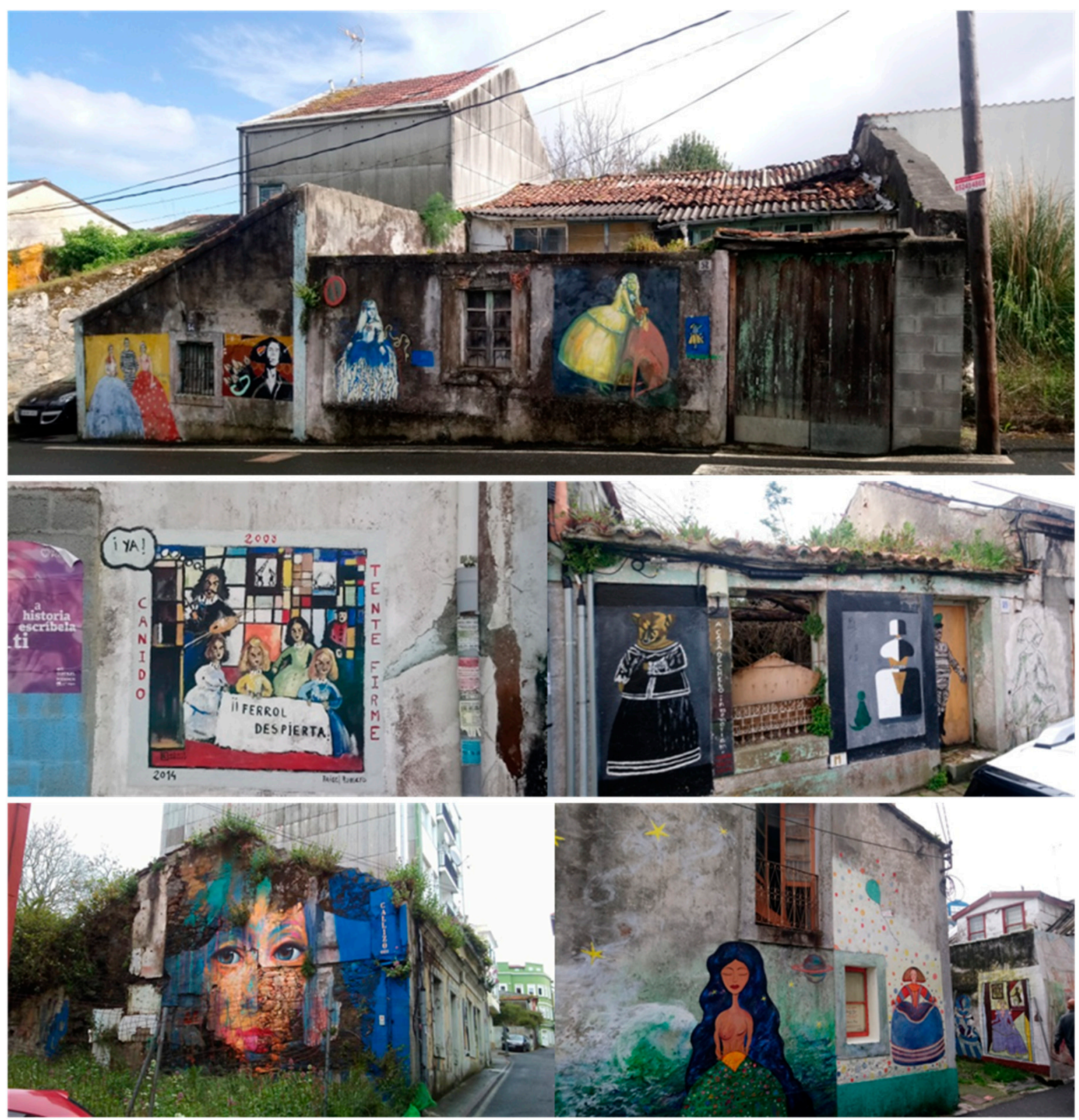

Figure 6. Meninas in the Canido neighborhood.

In addition, a mobile app known as VISUAR for IOS system and Visar Augmented Reality for Android mobiles have been created, through which information about the works can be obtained as well as some animations that can be seen by standing in front of them.

The festival has aroused interest in cities outside Spain, and Eduardo Hermida has given presentations in forums in Paris and Kiev. Other Spanish cities, such as Madrid, intend to develop a similar initiative in several districts, while other cities are also targeting chromatism. These include Cambre, with its Chromatic Mural Fest, or Carballo, with its initiative Breaking Down Walls with Paint (Figure 7). It has been shown that art has very positive effects, not only from the point of view of the physical improvement of neighborhoods but also of social valorization. 


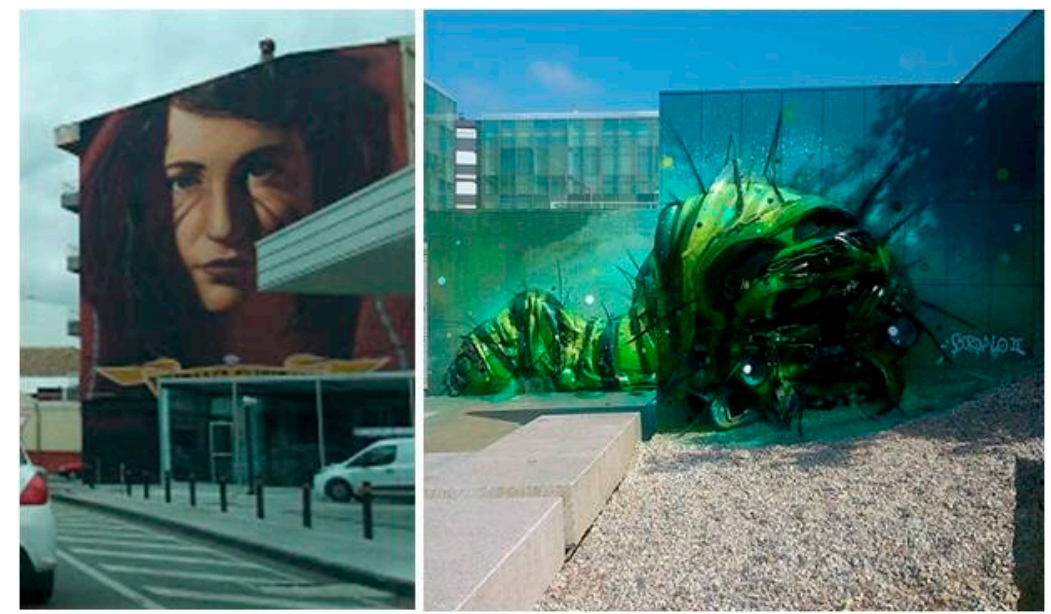

Figure 7. Murals in Carballo.

\subsection{The Impact of Meninas in the Neighborhood of Canido}

The interviews with the neighbors and entities of the neighborhood allow us to affirm that the cultural event of Las Meninas de Canido has managed to position the neighborhood on the map on an international scale. The neighborhood has regained its life and has become a fashionable space. As a consequence:

- The neighbors of Canido feel prouder than ever of their neighborhood and have reinforced a degree of identity with it. In the past, Canido was considered by the population of Ferrol as a degraded neighborhood, in which all the industries and amenities that "bothered people" (cemetery, factories, etc.) were historically located, where the working population was concentrated, and an whose residents were contrary to the regime of the dictator. No one wanted to live or say they lived in it.

- Canido has become a trendy neighborhood, which some people say resembles London's Soho. It is one of the most desired spaces in the city to live. It has become a different neighborhood: vital, enthusiastic, optimistic. It is a reconstructed neighborhood in which art itself is the identifying element and a tourist attraction. People want to live in the neighborhood, and this is how it has gone from having about 1300 inhabitants in 2008 to 7500 in 2018. The rise in land prices is another complement. While before you could buy a plot of land for less than $€ 20,000$, now, there is nothing below $€ 150,000$.

- It is currently an urban sector in which institutions are focusing their interest, understanding that the Meninas de Canido is an event that favors tourist activity, which was previously practically nonexistent in the city. Murals have become a focus of attraction for people who visit it (Figure 8). Everyday there is someone who walks the streets with a camera to take a picture of the murals. It is estimated that about 50,000 people visit the neighborhood every year in order to see Las Meninas.

- This momentum has also been supported by municipal urban renewal initiatives to provide it with more livable spaces: functional squares, benches, trees, or larger sidewalks are elements that improve livability. In some of them, Las Meninas are part of their urban furniture.

- Rehabilitation projects of some homes are being carried out in the key points of the neighborhood. Rehabilitations are mostly carried out by residents of the neighborhood with liberal professions and enough purchasing power to cover the cost of refurbishment and renovation. Without a doubt, it is the best way to keep residents and attract new ones.

- In the last five years, 27 businesses have opened. Hospitality and traditional commerce have noticed a revival in the neighborhood. The owners of traditional commerce affirm that this revitalization has allowed them to stay open and to have some stability. For its part, the hospitality sector acknowledges it has benefited and seen its bottom line improve, not only on the days when 
the Meninas are celebrated but also during the rest of the year, thanks to the activities being promoted since becoming a civic center of the neighborhood.

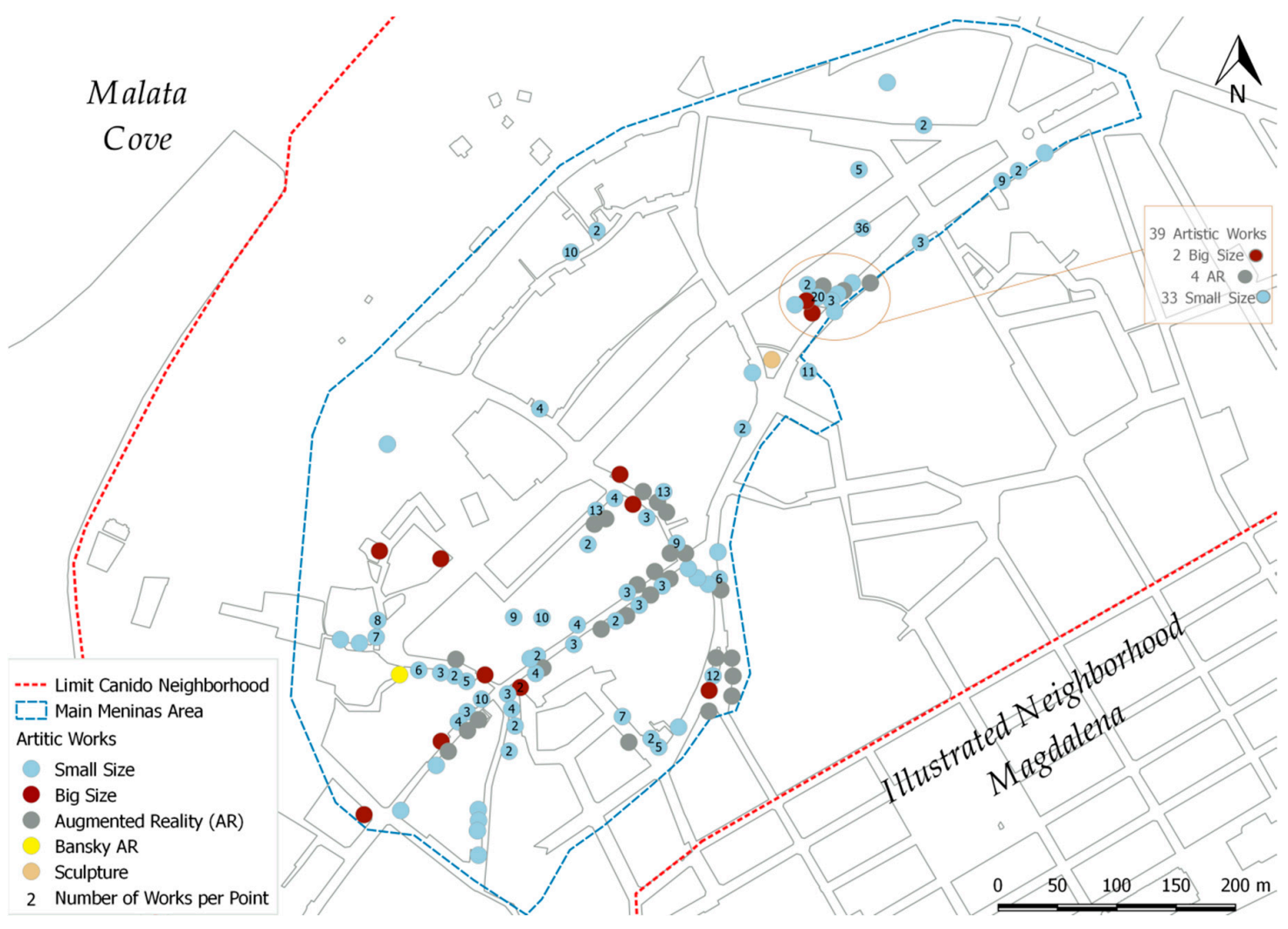

Figure 8. Distribution of the Meninas in Canido neighborhood.

Therefore, there is no doubt that Las Meninas have been a turning point whereby Canido is the fashionable neighborhood of Ferrol, and that both the city and the neighborhood have positioned themselves on the map at national and international levels. If Ferrol was the typical example of a shrinking city in permanent crisis as a result of the reconversion of the naval sector, the Meninas initiative has managed to transfer a new image of the city, more dynamic and with good practices in order to rehabilitate degraded spaces.

However, a part of the social and business fabric observes that the original idea has been progressively transformed, and that behind the Meninas event another reality is hidden that they want to show. They fear that the success of Las Meninas will be a screen that will leave other initiatives in the background that are not less important and launched by government institutions, neighborhood associations and the business community, as well as many other problems that remain unsolved.

First, they consider that, although Las Meninas began as a cultural initiative, a popular event, in which the neighbors collaborated with the artists and one in which the local hospitality industry played an active role organizing the meals, in recent years, it has become a more private event, with the emergence of a brand of beer as a sponsor, the commissioning of food services to companies outside the neighborhood and not to the bars in the area, and the hiring of personnel that do not belong to the neighborhood to attend said services. All this has meant a quantitative and qualitative change with respect to the original idea. Las Meninas have gone from being a neighborhood event, where the neighbors used to eat together in the street, with 400 people in the neighborhood sitting at a large table, to becoming an international event attended by more than 50,000 people in which the popular character has disappeared. Given this circumstance, and with the aim of recovering precisely that link with the neighborhood, the last edition decided to reduce the contribution of the sponsor and give more opportunities to the population and businesses of the neighborhood. 
On the other hand, if at the beginning the idea was for enthusiasts to paint Las Meninas on small walls or parts of houses, now, the tendency is for invited international artists to paint large murals on buildings. Obviously, these works are an element of attraction for visitors and tourists, who come to the neighborhood and have the opportunity to see real works of art in the street. However, the neighbors miss the freshness and initial spontaneity.

With regard to the neighborhood, it is true that Canido is now a pleasant and uncomplicated place to live. However, the Association of Neighbors state that this is not due to the Meninas movement so much but rather to an urban plan, of which little is said. It is a plan that modified the physiognomy of the neighborhood through the humanization of several streets (Alegre, A Rocha), the opening of new roads and the construction of a civic center. The interventions carried out in the Stone cross square turned this space (traditionally occupied by a small roundabout) into the epicenter of the neighborhood and a public space in which to socialize, taking away that functionality from Canido Square. In that same period, the plot occupied by the old Fenya factory was built upon. These homes were occupied by young families with medium-high purchasing power and with children, a circumstance that favored the socio-demographic rejuvenation of the neighborhood. On the other hand, there was an interest on the part of some neighbors to rehabilitate some homes in the neighborhood and stay there. In this sense, a study is being carried out on the existing properties in the neighborhood to analyze the possibility of rehabilitating them. More than 100 properties have been accounted for, all suffering from different levels of degradation. In any case, the recovery of some of them would be a significant improvement, and it would be a mechanism to improve the resident population in the neighborhood and to attract more residents with medium-high purchasing power. In this sense, it should be noted that gentrification processes have not yet been observed, as has happened in other Spanish or European cities, where cultural initiatives such as those of Las Meninas have been launched. At the moment, traditional rents remain stable, and there has been no replacement of the original population of the neighborhood.

There is a consensus on the part of retailers and hoteliers that the Meninas have managed to revitalize the neighborhood and generate a synergy of activism and participation by the business and associative fabric of the neighborhood, which was consolidated with the creation of Hoscompro, an association of merchants and hoteliers whose purpose was to energize life in the neighborhood. This association has always been collaborative with the association of neighbors of Canido, whose objective is to create a community project in the neighborhood, launching cultural activities, leisure and consolidating traditional festivals, which despite being less known than Las Meninas, provide equivalent income to the catering sector.

The neighborhood association seeks to generate and consolidate intra-neighborhood dynamics, collaborating with all the entities of the neighborhood (cultural, religious, sports) to seek a complicity that allows them to develop activities together and become a driver when requesting that institutions make greater investments in the neighborhood and improvement initiatives, both physically and socially. They insist that behind the festivity and the playful nature of Las Meninas lies a reality of sub-standard housing, streets affected by serious degradation, a high percentage of the population in a situation of endemic poverty, numerous elderly people living alone and without suitable services, while there is a deficit of spaces for young people who come to the neighborhood to play sports or games. Some successes have already been achieved, such as those derived from the "happy city" project, through which sports exhibitions, dance shows, musical performances, gastronomic routes, and even a curious slow bicycle race were held in different parts of the neighborhood.

What is definitively pursued by these processes of social construction of the urban space is to change the perception of the public about Canido. Thanks to Las Meninas, the urban imaginary of the neighborhood has been improved. The cultural action of the Girls has served as a loud protest against the situation of the crisis, as an element of tourist attraction that had not experienced before. However, we ask if the imaginary created on the barrio will not be surpassing the reality-hence, the insistence on the part of the association that we not see Canido as the new Soho, where everything is perfect and beautiful and all of the problems have been solved, but as a neighborhood where institutions need to 
continue investing to generate public spaces of coexistence, where people can play, dance, listen to music, or just chat with neighbors.

Eduardo Hermida, the promoter of Las Meninas, has the same opinion. He is aware that this event may continue for some time, but that it will have to come to an end. With the objective that the neighborhood continues to improve, from a physical, social, economic, and environmental point of view, several projects are already underway. Among them is the recovery of an agricultural green space, turning abandoned gardens into urban leisure spaces or environmental education spaces for schools in the area. For this they have already begun to plant fruit trees, turning this abandoned space into a meeting place for neighbors of all ages. Another collective artistic initiative consists of recovering the environment of the missing Hispania pencil factory by installing 40 wooden pencil-shaped posts, each with five faces and a height of $2.85 \mathrm{~m}$. This initiative aims to spread the experience of Las Meninas in the historic center of Ferrol, an area also affected by serious processes of urban deterioration; if successful, it could be used as a link between the two neighborhoods.

\section{Conclusions}

Street art can contribute to the physical sustainability of the degraded urban sector, one of the essential dimensions of the urban sustainability paradigm - together with economic, social, ecological, and political sustainability [81]. It has proven to be an effective alternative to recover urban spaces affected by abandonment, loss of population and identity, improving those spaces from a physical, social, and economic point of view and turning them into places of opportunity. Local administrations have found in it a tool for urban regeneration, which does not involve large investments and which, in return, brings great benefits, since they are spaces that increasingly attract more tourists and position their cities internationally. However, by way of conclusion, we must reflect on the following issues:

- How to manage/control the processes of gentrification, elitization, and tourism that can be registered in neighborhoods where street art is successful in order to preserve the harmony of the neighborhood and avoid as far as possible the expulsion of its residents.

- What situations are conducive to the success of street art, and what is the degree of dependence on this activity. Could there be a reversal of the dynamic process that these neighborhoods undergo if these artistic competitions end? Will the neighborhood still have the same social and economic strength?

- If we start from the fact that street art contests arise in most cases at the initiative of some artists or groups of citizens, with the support of the administrations, the future of the neighborhood should be designed together between all parties, promoting complementary actions that strengthen the quality of life of residents in the neighborhood and consolidate their economic and social revitalization in the medium term.

In the case of Canido, the Las Meninas movement has managed to save the neighborhood from a slow death and put it in the spotlight of international artists and tourists from around the world who visit the festival. However, the limit of availability of spaces in which to make the paintings is being reached, and although other artistic initiatives that try to have the same success in other nearby urban sectors have already been launched, it may not be the same Success achieved with Las Meninas. We hope that all the agents involved—neighbors, associations, and local administration-are able to jointly design a program of integral intervention in the neighborhood that guarantees its dynamism, quality of life, and urban sustainability.

Author Contributions: F.R.D.V., M.J.P.M., and R.L.R. contributed to the conception and design, data analysis, and manuscript preparation. M.J.P.M. and R.L.R. contributed to the interviews. F.R.D.V. and M.J.P.M. contributed to proofreading and editing. R.L.R. contributed to mapping. F.R.D.V., M.J.P.M., and R.L.R. contributed to the interpretation of the results. All authors have read and agreed to the published version of the manuscript.

Funding: This research was funded by the Spanish Ministry of Economy and Competitiveness (MINECO) New Models for Governing Cities and Intervention in Urban Spaces in the Post-Crisis Period (CSO2016-75236-C2-1-R). 
Conflicts of Interest: The authors declare no conflict of interest.

\section{References}

1. Eizaguirre, S.; Pradel, M.; Terrones, A.; Martinez-Celorrio, X.; García, M. Multilevel governance and social cohesion: Bringing back conflict in citizenship practices. Urban Stud. 2012, 49, 1999-2016. [CrossRef]

2. García-Cabeza, M.S. State-led real estate boosterism and the breakdown of the Spanish urban model. In Debating the Neo-Liberal City, 1st ed.; Pinson, G., Morel-Journel, C., Eds.; Routledge: London, UK, 2017; pp. 174-187.

3. Del Romero-Renau, L.; Valera-Lozano, A. From NIMBYsm to the 15M: A decade of urban conflicts in Barcelona and Valencia. Territ. Politics Gov. 2016, 4, 375-395. [CrossRef]

4. Koutrolikou, P. Governmentalities of urban crises in inner-city Athens, Greece. Antipode 2016, 48, 172-192. [CrossRef]

5. Vale, M. Economic crisis and the Southern European regions: Towards alternative territorial development policies. In Identity and Territorial Character. Re-Interpreting Local-Spatial Development, 1st ed.; Salom, J., Farinós, J., Eds.; Universidad de Valencia: Valencia, Spain, 2014; pp. 37-48.

6. Fernández Maíllo, G. VIII Informe Sobre Exclusión y Desarrollo Social en España; Fundación Foessa: Madrid, Spain, 2019.

7. Mínguez, C.; Piñeira, M.J.; Fernández-Tabales, A. Social Vulnerability and Touristification of Historic Centers. Sustainability 2019, 11, 4478. [CrossRef]

8. Méndez, R.; Abad, L.D.; Echaves, C. Atlas de la Crisis. Impactos Socioeconómicos y Territorios Vulnerables en España; Tirant lo Blanch: Valencia, Spain, 2015.

9. Piñeira, M.J.; Trillo, J.M. The effect of the crisis on vulnerable neighbourhoods: An approximation of the Spanish context through a case study (A Coruña, Galicia). In Crisis, Globalization and Social and Regional Imbalances in Spain; Spanish Commitee IGU: Madrid, Spain, 2016; pp. 136-148.

10. Piñeira, M.J.; Durán, F.R.; Taboada, J. Urban Vulnerability in Spanish Medium-Sized Cities during the Post-Crisis Period (2009-2016). The Cases of a Coruña and Vigo (Spain). Urban Sci. 2018, 2, 37. [CrossRef]

11. Alguacil, J.; Camacho, J.; Hernández, A. La vulnerabilidad urbana en España. Identificación y evolución de los barrios vulnerables. Empiria. Rev. Metodol. Cienc. Soc. 2014, 27, 73-94. [CrossRef]

12. Nel.lo, O. Transform the City with Citizenship. Criteria and Reflections for the Barrio. Plan of Barcelona; Ayuntamiento de Barcelona: Barcelona, Spain, 2017.

13. Hernández, A.; Matesanz, A.; García, C.; Alguacil, J.; Camacho, J.; Fernández, C. Atlas de Barrios Vulnerables de España: 12 Ciudades 1991/2001/2006; Instituto Juan de Herrera: Madrid, Spain, 2015.

14. Wehrhahn, R. Contentious urban housing politics in European metropolises between financialisation, dispossession and re-possession: Jahrbuch StadtRegion. In Housing and Housing Politics in European Metropolises; Wehrhahn, R., Pohlan, J., Hannemann, C., Othengrafen, F., Schmidt-Lauber, B., Eds.; Springer: Wiesbaden, Germany, 2019; pp. 3-20.

15. Koutrolikou, P. Changing landscapes of urban citizenship: Southern Europe in times of crisis. Citizsh. Stud. 2017, 21, 379-392.

16. Heernan, E.; McHale, J.; Moore-Cherry, N. Debating Austerity in Ireland: Crisis, Experience and Recovery; Royal Irish Academy: Dublin, Ireland, 2017.

17. Janoschka, M. Who Loses and Who Wins in a Housing Crisis? Lessons from Spain and Greece for a Nuanced Understanding of Dispossession. Hous. Policy Debate 2017, 28, 117-134.

18. Blanco, A.; Blázquez, M.; Canoves, G. Barcelona, Housing Rent Bubble in a Tourist City. Social Responses and Local Policies. Sustainability 2018, 10, 2043. [CrossRef]

19. Blanco, A.; Subirats, J. Políticas urbanas en España: Dinámicas de transformación y retos ante la crisis. Geopolítica(s) 2012, 3, 15-33.

20. Pradel Miquel, M.; García Cabeza, M. El Momento de la Ciudadanía: Innovación Social y Gobernanza Urbana; Catarata: Barcelona, Spain, 2018.

21. Burriel de Orueta, E. La década prodigiosa del urbanismo español (1997-2006). Scr. Nova Rev. Electrón. Geogr. Cienc. Soc. 2008, 12, 64 . 
22. Lois González, R.C.; Piñeira Mantiñán, M.J. Urban development processes in Spain—From consolidated cities to urban regions with an over densified housing market. In Contemporary Problems of Urban and Regional Development; Mierzejewsa, L., Wdowicka, M., Eds.; Bogucki: Poznan, Poland, 2011; pp. 61-71.

23. Rullan Salamanca, O. Urbanismo expansivo en el Estado Español: De la utopía a la realidad. In Geografía y Desafíos Territoriales en el Siglo XXI.; Gozálvez, V., Marco, J.A., Eds.; Asociación de Geógrafos Españoles \& Universidad de Alicante: Alicante, Spain, 2012; pp. 165-209.

24. De Gregorio Hurtado, S. El desarollo de las iniciativas comunitarias Urban y Urban II en las periferias degradadas de las ciudades españolas. Una contribución a la práctica de la regeneración urbana en España. Ciudades 2010, 13, 39-59.

25. Ministry of Development. URBACT Program. Available online: www.rediniciativasurbanas.es/convocatoriade-ayudas/urbact (accessed on 3 January 2020).

26. Ministry of Development. Integrated and Sustainable Urban Development Strategy. Available online: www.rediniciativasurbanas.es/convocatoria-de-ayudas/estrategias-dusi (accessed on 3 January 2020).

27. Casagrande, M. Urban Acupuncture. Available online: http://thirdgenerationcity.pbworks.com/f/urban $\%$ 20acupuncture.pdf (accessed on 3 January 2020).

28. Alcalá Agulló, F.; Jménez Sánchez, F. Los Costes Económicos del Déficit de Calidad Institucional y la Corrupción en ESPAÑA; Fundación BBVA: Bilbao, Spain, 2018.

29. Center for Sociological Research. Three Main Problems That Currently Exist in Spain (Multi-Response\%) (2007-2019). Available online: www.cis.es/cis/export/sites/default/-Archivos/Indicadores/documentos_html/ TresProblemas.html (accessed on 3 January 2020).

30. Harvey, D. Ciudades Rebeldes. del Derecho de la Ciudad a la Revolución Urbana; Akal: Madrid, Spain, 2012. [CrossRef]

31. Ekers, M.; Hamel, P.; Keil, R. Governing suburbia: Modalities and mechanisms of suburban governance. Reg. Stud. 2012, 46, 405-422. [CrossRef]

32. McLeod, G. Urban politics reconsidered: Growth machine to post-democratic city. Urban Stud. 2011, 48, 2629-2660. [CrossRef]

33. Romero, J.; Farinós, J. Redescubriendo la gobernanza más allá del buen gobierno. Democracia como base, desarrollo territorial como resultado. Boletín Asoc. Geógrafos Españoles 2011, 56, 295-319.

34. Swyngedouw, E. Governance innovation and the citizen: The Janus face of governance-beyond-the-state. Urban Stud. 2005, 42, 1991-2006. [CrossRef]

35. Peck, J.; Theodore, N.; Brenner, N. Neoliberalism resurgent? Market rule after the great recession. South Atl. Q. 2012, 111, 265-288. [CrossRef]

36. Storper, M. Keys to the City. How Economics, Institutions, Social Interaction and Politics Shape Development; Princeton University Press: Oxford, UK, 2013.

37. Lois, R.; Macía, C.; Piñeira, M.J.; Calvo, A. Smart cities and regions in Europe. In Life in a Changing Urban Landscape; Kotze, N., Donaldson, R., Visser, G., Eds.; University of Johannesburg: Johannesburg, South Africa, 2014; pp. 27-36.

38. European Commission. Local and Regional Partners Contributing to Europe 2020: Multi-Level Governance in Support of Europe 2020; European Commission: Brussels, Belgium, 2015.

39. Hatfield, S.; Nelson, R.; Cook, D. Adaptive Governance: An Introduction and Implications for Public Policy; Australian Agricultural and Resource Economics Society: Queenstown, Ireland, 2007.

40. Howlett, M.; Ramesh, M. Three orders of governance failure: Policy capacity, problem context and design mismatches. In Proceedings of the 23rd World Congress (Challenges of Contemporary Governance), Montreal, QC, Canada, 20-25 July 2014; IPSA: Montreal, QC, Canada, 2014.

41. Steurer, R. Disentangling governance: A synoptic view of regulation by government, business and civil society. Policy Sci. 2013, 46, 387-410. [CrossRef]

42. Cabreirizo, C.; Klett, A.; García, P. De alianzas anómalas a nuevos paisajes políticos. Madrid, Lavapiés y otras geografías de lo común. Urbs. Rev. Estud. Urbanos Cienc. Soc. 2014, 5, 163-178.

43. Allmendiger, P.; Haughton, G. Spatial planning, devolution, and new planning spaces. Environ. Plan. Gov. Policy 2010, 28, 803-818. [CrossRef]

44. Méndez, R. Crisis económica, vulnerabilidad urbana y desempleo en España. Ciudad Territ. Estud. Territ. 2013, 178, 649-667. 
45. Stocker, G.; Wilson, D. British Local Government: An Assessment of Labour's Reform Programme; Palgrave Macmillan: Basingstoke, UK, 2004.

46. Harvey, D. De la gestión al empresarialismo: La transformación de la gobernanza urbana en el capitalismo tardío. In Espacios de Capital, Hacia una Geografía Crítica; Harvey, D., Piña, C., Eds.; Akal: Madrid, Spain, 2007.

47. Lois, R.; Piñeira, M.J.; Vives, S. The urban bubble process in Spain: An interpretation from the theory of circuits of capital. J. Urban Reg. Anal. 2016, 8, 5-20.

48. Lois, R.C.; Piñeira, M.J. The revival of urban social and neighbourhood movements in Spain: A geographical characterization. DIE ERDE 2015, 146, 127-138.

49. Delgado Jiménez, A. De la participación ciudadana a la gobernanza urbana: Transformaciones políticas y territoriales. Ciudad. Para Futuro Más Sosten. Boletin C $f+S$ 2009, 44, 67-78.

50. Newman, J. Remaking Governance: Peoples, Politics and the Public Sphere; Policy Press: Bristol, UK, 2005.

51. Durán Villa, F.R.; Piñeira Mantiñán, M.J. Evictions and the social crisis in Spanish cities. In Urban Challenges in a Complex World: Resilience, Governance and Changing Urban; Moore-Cherry, N., Ed.; University College Dublin \& IGU: Dublin, Ireland, 2015; pp. 80-85.

52. Valiño, V. Emergencia Habitacional en el Estado Español: La Crisis de las Ejecuciones Hipotecarias y Los Desalojos Desde una Perspectiva de Derechos Humanos; Observatorio OESC, PAH: Barcelona, Spain, 2013.

53. Moulaert, F.; Martinelli, F.; Swyngedouw, E.; Gonzalez, S. Towards alternative model(s) of local innovation. Urban Stud. 2005, 42, 1969-1990. [CrossRef]

54. Murray, R.; Mulgan, G.; Caulier, J. How to Innovate: The Tools for Social Innovation; The Young Foundation and Nesta: London, UK, 2011.

55. Blanco, I.; Cruz, H.; Martínez, R.; Parès, M. El papel de la innovación social frente a la crisis. Ciudad Territ. 2016, 48, 49-260.

56. Sacco, P.L.; Ferilli, G. Il Distretto Culturale Evoluto Nell'economia Post Industriale; DADI, Università IUAV: Venezia, Italy, 2006.

57. Arte Urbano. Available online: www.significados.com/arte-urbano/ (accessed on 3 December 2019).

58. Ballaz, X. El graffiti como herramienta social. Una mirada psicosocial a las potencialidades críticas del arte urbano. In Violencia y Salud Mental Salud Mental y Violencias Institucional, Estructural, Social y Colectiva; Markez Alonso, I., Fernández Liria, A., Perez-Sales, P., Eds.; A.E.N Estudios: Madrid, Spain, 2009; pp. 131-144.

59. Allende, S. Street Art. Catálogo de la Exposición Arte Urbano de la Calle al Museo; Consejería de Cultura y Portavocía; Comunidad Autónoma de la Región de Murcia: Murcia, Spain, 2017.

60. Visconti, L.M.; Sherry, J.F.; Borghini, S.; Anderson, L. Street art, sweet art? Reclaiming the "Public" in public place. J. Consum. Res. 2010, 37, 511-529. [CrossRef]

61. Loeffler, S. City as Skin: Urban Imaginaries of Flesh and Fantasy. Archit. Des. 2013, 83, 114-119. [CrossRef]

62. Molina, G.; Guinard, P. Arts in Cities-Cities in Arts. Artic. J. Urban Res. 2017, 15.

63. Baudrillard, J. Le Système des Objets; Éditions Gallimard: Paris, France, 1968.

64. Tornaghi, C. Questioning the Social Aims of Public Art in Urban Regeneration Initiatives. The Case of Newcastle upon Tyne and Gateshead (UK); University of Milano-Bicocca: Milan, Italy, 2008.

65. Gómez Aguilera, F. Arte, Ciudadanía y Espacio Público. W@Terfront 2004, 5, 36-51.

66. The Bushwick Collective. Available online: https://artsandculture.google.com/exhibit/gRPwr3J5 (accessed on 5 November 2019).

67. Wynwood Walls. Available online: www.thewynwoodwalls.com/overview (accessed on 5 November 2019).

68. Ramil, E.; Llorca, G.; Rodríguez, J.A. Historia de Ferrol; Via Lactea: La Coruña, Spain, 1998.

69. Pérez, S. Gabriel Vázquez Seijas. Memoria de Vida. Salamanca; Gráficas Lope: Salamanca, Spain, 2001; pp. 393-414.

70. Kapstein, P. Vulnerabilidad y Periferia Interior. Cuad. Investig. Urban. 2010, 71, 7-114.

71. Madoz, P. Galicia. Diccionario Madoz; Breogán: Santiago de Compostela, Spain, 1986; Volume 3, pp. 537-538.

72. Montero, J. Historia y Descripción de El Ferrol; Gersan: Puentedeume, Spain, 1986; pp. 203-204.

73. Abeconsa Prepares to Launch Its Great Promotion in Canido. Available online: www.lavozdegalicia.es/noticia/ ferrol/2019/09/14/abeconsa-prepara-lanzar-gran-promocion-canido/0003_201909F14C2992.htm (accessed on 5 November 2019).

74. Galician Institute of Statistics. Available online: www.ige.eu/estatico/estat.jsp?ruta=html/gl/ PanoramaConcellos/02_Poboacion.html (accessed on 5 November 2019). 
75. Canido Will Receive the Award on Wednesday for Being Considered the Best Neighborhood in Galicia. Available online: www.diariodeferrol.com/articulo/ferrol/canido-recibira-miercoles-galardonser-considerado-mejor-barrio-galicia/20190610000218258368.html (accessed on 5 November 2019).

76. Castells, M. Globalización e Identidad. Quad. Mediterr. 2010, 14, 254-262.

77. The Neighborhood of Canido Is Once Again Pulled with Its Market. Available online: www.lavozdegalicia. es/noticia/ferrol/ferrol/2019/09/10/barrio-canido-vuelve-tener-tiron-mercado/0003_201909F10C12991.htm (accessed on 5 November 2019).

78. A Market That Took the Urban Garden to Canido. Available online: www.lavozdegalicia.es/noticia/ferrol/ 2013/09/21/mercado-llevo-huerta-canido/00031379775449214304300.htm (accessed on 5 November 2019).

79. The Art of Mercalegre Was Completed in This Edition with Music and Theater. Available online: $\quad$ www.diariodeferrol.com/articulo/ferrol/arte-mercalegre-completo-edicion-musica-teatro/ 20180708224309230793.html (accessed on 5 November 2019).

80. The Route of the Canido Meninas in Ferrol (with Banksy?). Available online: https://saltaconmigo.com/blog/ 2017/09/ruta-de-las-meninas-canido-ferrol-banksy/ (accessed on 5 November 2019).

81. Forte, F.; De Paola, P. How Can Street Art Have Economic Value? Sustainability 2019, 11, 580. [CrossRef]

(C) 2020 by the authors. Licensee MDPI, Basel, Switzerland. This article is an open access article distributed under the terms and conditions of the Creative Commons Attribution (CC BY) license (http://creativecommons.org/licenses/by/4.0/). 